\title{
Online Platforms, Rate Parity, and the Free Riding Defence
}

\author{
Simonetta Vezzoso (Trento University) \\ simonetta.vezzoso@unitn.it \\ Prepared for presentation at $11^{\text {th }}$ ASCOLA Conference \\ Leiden Law School, 30 June - 2 July 2016
}

(Draft version: 29 June 2016)

\begin{abstract}
A two-sided platform business is a new type of intermediary to be found in a growing number of economic sectors. As to the hospitability industry in particular, recent innovations in the field of digital technologies prompted the rise of so called Online Travel Agents (OTAs) and the demise of the traditional merchant model.

Recently national competition authorities (NCAs) in the EU investigated so called rate parity clauses in the contracts between the three largest OTAs and their hotel partners. These are contract clauses laying down the hotelier's obligation to display the same room prices across sales channels. The parallel investigations conducted by the NCAs revealed an array of serious anticompetitive effects stemming from rate parity obligations. While the German NCA concluded that there was insufficient evidence of the efficiency gains of these clauses, and therefore decided to prohibit them, the French, Italian and Swedish NCAs implicitly recognised that some level of protection against free-riding was necessary, and accepted commitments to reduce the scope of the rate parity obligation.

The hotel online booking cases were closely followed in the EU and beyond, since they could help clarify a number of key assessment issues concerning a category of commercial practices already widely spread in online markets. In-depth analyses of the NCAs' findings are now needed, especially in view of the promotion of an effective antitrust-based platform regulation. In particular, this article explores some of the challenges related to the application of the traditional free-riding defence to rate parity obligations.
\end{abstract}

Keywords: Online Platform, Online Travel Agent, Retail Most Favoured Nation Clause, Across Platform Parity Agreement, Rate Parity, Vertical Agreement, Exemption, Free Riding, Efficiency Gains, Consumer Pass-On

JEL CODES: : D43, K21, L1, L42

SUMMARY: 1. Introduction.- 2. The Online Hotel Booking Cases: Rate Parity on the Radar of Competition Authorities.- 2.1. Online Travel Agents and Retail Most Favoured Nation Clauses.-2.2. Anticompetitive Effects of Retail MFN clauses.2.3. The Free-Riding Defence.- 3. The Efficiency Defence as Applied to Narrow Retail MFN Clauses.- 3.1. Efficiency gains and the free-riding problem.- 3.2. Fair share.- 3.3. The question of out-of-market efficiencies.- 3.4 Alternatives to the Retail MFN Clause.- 4. Conclusion: The Free-riding Defence in the Digital Economy. 


\section{Introduction}

Online platforms characterize today's digital landscape, and their triumphal march throughout the world ${ }^{1}$ and into a growing number of economic sectors coincides with an increasing focus on their regulation. ${ }^{2}$ Horizontal and vertical restraints, abuses of dominant position, and merger cases involving online platform businesses are all equally high on the enforcement agendas of competition authorities.

As with other competition restraints, vertical agreements in digital markets create particular enforcement challenges. ${ }^{3}$ This is illustrated clearly also by the recent online hotel booking cases in the EU, in which national competition authorities (NCAs) have investigated so called rate parity clauses in the contracts between the three largest online travel agents (OTAs) and their hotel partners. These are contract clauses laying down the hotelier's obligation to display the same room prices across sales channels. In January 2010, the German NCA (Bundeskartellamt) began an investigation into a rate parity obligation found in the contracts between Hotel Reservation Service Robert Ragge $\mathrm{GmbH}$ (HRS), an online hotel booking portal, and its hotel partners. In December 2013, the Bundeskartellamt concluded ${ }^{4}$ that the rate parity clause between HRS and hoteliers was a vertical agreement restricting competition in the sense of Article 101(1) TFEU, and that neither the Vertical Block Exemption Regulation ${ }^{5}$ applied, nor there were reasons to justify an individual exemption under Article 101(3) TFEU. The Bundeskartellamt therefore ordered HRS to remove the rate parity clauses from its contracts with hotels and also launched investigations into similar agreements concluded by Expedia and Booking, the other two main OTAs operating on the German market. HRS appealed the decision to the Düsseldorf Higher Regional Court,

\footnotetext{
${ }^{1}$ See P. Evans, A. Gawer, The Rise of the Platform Enterprise: A Global Survey, The Center for Global Enterprise (2016), available at http://thecge.net/wp-content/uploads/2016/01/PDF-WEB-PlatformSurvey_01_12.pdf.

2 See European Commission, Online Platforms and the Digital Single Market Opportunities and Challenges for Europe, Communication, 25 May 2016, COM(2016) 288 final.

${ }^{3}$ See J. Hederström and L. Peeperkorn, Vertical Restraints in On-line Sales: Comments on Some Recent Developments, Journal of European Competition Law \& Practice (2016), 7(1), p.14 ff. In particular, the Authors identify three essential characteristics of online sales that may create new challenges for the competition assessment of vertical restraints, namely service-isation, de-passivisation, and platformisation. The focus of the present article is on the latter.

4 Bundeskartellamt, Hotel Reservation Service (HRS), Case B 9-66/10.

5 OJ L 102, 23.04.2010, p.1-7.
} 
and the appeal was rejected in January 2015.6 Although similar competition concerns were expressed by the French NCA (Autorité de la concurrence), the Italian NCA (Autorità Garante della Concorrenza e del Mercato), and the Swedish NCA (Konkurrensverket) in their respective investigations into Booking's rate parity clauses, the triad of NCAs decided, in strict cooperation with the European Commission 7 , to accept identical commitments from the OTA to restrict the scope of the rate parity obligation. ${ }^{8}$ Following the decisions of the triad of NCAs, Booking unilaterally extended the implementation of the commitments to its contracts with hoteliers throughout the EU9 ${ }^{9}$, followed by Expedia. However, in December 2015, the German NCA decided to prohibit the same 'minor' rate parity clause that Booking agreed on with the other NCAs within the framework of their respective commitment proceedings. ${ }^{10}$

The hotel online booking saga was closely followed in the EU and beyond, in particular because of its potential to clarify a number of key assessment issues concerning a category of commercial practices already widely spread in online markets. ${ }^{11}$ The largely parallel investigations conducted by NCAs revealed an array of serious anticompetitive effects stemming from rate parity obligations. In their defence, the OTAs alleged, inter alia, that without rate parity their specific efforts and investments aimed to match the two market sides, namely hoteliers and prospective travellers, could be exploited by free-riders. In the HRS and Booking decisions, the German NCA concluded that there was insufficient evidence of the efficiency gains of rate parity obligations. Instead, by accepting the commitments, the three competition

\footnotetext{
${ }^{6}$ Düsseldorf Higher Regional Court (OLG), VI - Kart. 1/14 (V).

${ }^{7}$ So called "enhanced cooperation" was established between the French, Italian and Swedish authorities to investigate the Booking case as a priority, coordinated by the European Commission.

${ }^{8}$ Autorité de la concurrence, Case 15-D-06; Konkurrensverket, Case 596/2013 ; Autorità Garante della Concorrenza e del Mercato, Case I779 B.

9 Cfr. http://news.booking.com/en-us/bookingcom-toamend-parity-provisions-throughouteuropeus/,

${ }^{10}$ Bundeskartellamt, Booking, Case B 9-121/13 (appeal is pending).

11 See ICN, Online Vertical Restraints Special Project Report (2015), available at http://www.internationalcompetitionnetwork.org/uploads/library/doc1070.pdf. The Report indicated a relatively higher degree of concern about rate parity clauses in the EU than elsewhere among ICN members.
} 
authorities implicitly recognised that some sort of protection against free-riding was indeed warranted. ${ }^{12}$

Given the discrepancies in the decisions taken by NCAs in the EU, concerns were expressed about regulatory fragmentation, and valuable suggestions have been made about how to clarify the legal status of rate parity clauses in the EU. ${ }^{13}$ While regrettable especially in terms of the legal uncertainty caused ${ }^{14}$, the current divergence between NCAs within the EU is not totally surprising, in particular due to the novelty of many of the issues involved. ${ }^{15}$ In-depth analyses of the NCAs' findings in the online hotel booking cases are now needed, in particular in view of an effective antitrust-based platform regulation. ${ }^{16}$ Besides helping promote a timely debate on some of the more general issues, the main contribution of this article is to illustrate some of challenges of applying the traditional free-riding defence to rate parity clauses.

12 See the French contribution to the OECD Hearing on across platform parity agreements (2015), $\$ 47$
("several factors suggest that in the total absence of an APPA there would be a real risk of free riding
in the online hotel booking sector, but this risk would vary depending on the distribution channel").
${ }^{13}$ See UK House of Lords, Online Platforms and the Digital Single Market, 10th Report of Session 2015-2016
(2016), available at http://www.publications.parliament.uk/pa/ld201516/ldselect/ldeucom/129/129.pdf; N. Sahuguet, J. Steenbergen, T. Vergé, and A. Walckiers, Vertical Restraints: Towards Guidance to Iron Out Perceived Enforcement Discrepancies Across Europe?, in Journal of European Competition Law \& Practice (2016), 7(4), p.274 ff; P. Akman, A Competition Law Assessment of Platform Most-Favoured-Customer Clauses, Working Paper, University of Leeds (2015).

${ }^{14}$ While NCAs could not agree on some ingredients of the assessment, this might have encouraged some national legislators to intervene and take sides on this politically sensitive debate. Thus, in July 2015 France passed legislation outlawing retail MFN clauses in the hotel sector, see Loi $n^{\circ} 2015-990 \mathrm{du} 6$ août 2015 pour la croissance, l'activité et l'égalité des chances économiques, Article L.311-5-1 («hoteliers remain free to grant their customers any rebate or tariff advantage, and any clause to the contrary shall be deemed null and void»). Legislators in other countries, in particular Italy and Austria, are currently discussing the introduction of an outright ban on rate party.

${ }_{15}$ Possibly, the dissent among NCAs could even be valuable, at least to some extent, in terms of transparency and potential contribution to the scientific debate. Oftentimes, well-founded and intellectually engaging differentials between competition authorities are dealt with behind the impenetrable doors of the European Competition Network.

16 See also the already mentioned the 2015 OECD Hearing, supra note 12 and the ICN Special Project, supra note 11 . 


\section{The Online Hotel Booking Cases: Rate Parity on the Radar of Competition}

\section{Authorities}

\subsection{Online Travel Agents and Retail Most Favoured Nation Clauses}

The constant and unrelenting flow of innovations in the field of digital technologies is deeply affecting the competitive dynamics of most economic sectors. As to the hospitality industry in particular, new technologies have prompted the rise of a specific breed of online platforms called Online Travel Agents (OTAs) ${ }^{17}$. Online

platforms are "intermediaries bringing together various groups of users so that they can interact economically or socially". ${ }^{18}$ The basic idea behind the rise of these businesses in the digital economy is that it is not always profitable to charge a (direct) price to all the end-users of the services that an undertaking can provide. In the case of a search platform, for instance, instead of charging platform users for the search services, it makes economic sense to charge those who seek access to the users, in particular advertisers. In this setting, a business is successful when it is capable to ensure that those different user groups interact and create value in the (technological) environment created by the platform itself. This in turn is strengthened by the presence of network effects, meaning that the more users the platform has, the more valuable the platform becomes to other users. Furthermore, mining and processing of user data can increase the experience of the services provided by the platform to one or more user groups (e.g., better search results and/of more effective, targeted advertisement campaigns). ${ }^{19}$

\footnotetext{
17 In 1996, Microsoft launched the first OTA allowing customers to book hotel rooms online, called Expedia Travel Services, see 'Microsoft Expedia Travel Services Debuts on the Web', available at http://news.microsoft.com/1996/10/22/microsoft-expedia-travel-services-debuts-on-the-web/.

Microsoft sold Expedia in 2001 to USA Networks, see Forbes, 'Microsoft Sells Expedia Stake, Learns Lesson', available at http://www.forbes.com/2001/07/16/0716expedia.html. Prior to Microsoft, Sabre Corporation - a former American Airlines subsidiary - launched Travelocity, the first portal on which consumers could book and purchase airline tickets online. In 2015, Expedia acquired Travelocity from Sabre for $\$ 280$ million, see Sabre's press announcement, http://www.sabre.com/insights/releases/sabre-and-expedia-announce-expedias-acquisition-oftravelocity/.

${ }_{18}$ See UK House of Lords (2016), supra note 13, p. 189 (citing the testimony provided by the German Monopolies Commission).

${ }^{19}$ Amidst the most recent contributions on online platforms in general, see European Commission, Staff Working Document on Online Platforms and the Digital Single Market, 25 May 2016, SWD(2016) 172 and Bundeskartellamt, Marktmacht von Plattformen und Netzwerken, Working Paper, June 2016.
} 
As to OTAs in particular, they are profoundly different from traditional travel agents securing an inventory of rooms at wholesale rates from hotels and reselling them at a marked up retail rate. ${ }^{20}$ OTAs provide a technologically enabled interface between different groups of users, namely the hoteliers and the prospective travellers, allowing them to find each other and to transact. While the platform provides matchmaking services to both groups of users, OTAs in the online hotel booking market have currently opted for a business model that does not charge final consumers directly ${ }^{21}$ for such services, but levies a commission fee (cost-per-acquisition - CPA- fee) on hotels when transactions are executed. Hoteliers unilaterally set retail prices to final consumers, whereas OTA-to-hotel negotiations determine the level of the CPA fees.

In the course of their respective investigations, NCAs revealed that the contracts between Booking, Expedia and HRS (the three largest OTAs) and their hotel partners contained retail Most Favoured Nation (MFN) clauses. ${ }^{22}$ A wide retail MFN agreement requires a hotelier not to advertise the same room for the same night at a lower price through any alternative OTA, or any other sales channel, including the hotel's own website and offline booking facilities. Where a wide retail MFN applies, a prospective customer of a specific hotel retains the choice to book her room directly from the hotelier, or indirectly through competing platforms and other distribution channels. Whatever the route taken, however, by virtue of the wide retail MFN in place between the OTA and the hotelier, the consumer pays exactly the same price for her hotel stay

\footnotetext{
${ }^{20}$ In the relatively short space of two decades, the distribution in the hospitality industry has shifted from a merchant model to a commission based (or agency) model. Under the formerly dominant merchant model, the travel agent had control over the entire retail transaction, from setting the retail rate of the hotel room and collecting the payment, to establishing the cancellation policy and providing customer service.

${ }^{21}$ It has already become commonplace to hold that users of online platforms pay allegedly free services with their personal data, see UK House of Lords (2016), supra note 13, p. 4 ("Consumers seem to be unaware that they trade their personal data in exchange for access to many of the so-called 'free services' that online platforms provide").

${ }^{22} \mathrm{~A}$ retail MFN agreement requiring the hotel to price its rooms on the partner platform no higher than on other platforms could also be called an across-platforms parity agreement (APPA), see LEAR, Can 'Fair' Prices Be Unfair? A Review of Price Relationship Agreements (2012), available at http://www.learlab.com/wp-content/uploads/2016/04/Can-\%E2\%80\%98Fair\%E2\%80\%99-PricesBe-Unfair_-A-Review-of-Price-Relationship-Agreements.pdf, p. $94 \mathrm{ff}$. A recent contribution by the International Competition Network (over-) stretches the definition of APPAs to include also narrow retail MFNs, see ICN (2015), supra note 11, p. 66 ("The restraint may also apply to the supplier's own online and/or offline platform(s)"). It is clear, however, that the hotel's traditional website for room reservation can hardly be seen as a platform.
} 
(full rate parity). ${ }^{23}$ Instead, a narrow retail MFN requires the hotelier to charge the same price to consumers via its own-website, by phone, at the hotel desk, etc., as the hotelier offers through the partner platform, but does not restrict the hotelier from displaying a lower room price on other platforms (limited rate parity). This means that under narrow retail MFN the hotel could in principle display different prices for the same room on competing platforms. If the hotelier wishes to increase the price of the room displayed on the partner platform benefiting from a narrow MFN clause, however, this increase should be reflected on the room rates available on the hotel's website and on the other own sales channels.

While retail MFN clauses could be found in principle also in offline environments ${ }^{24}$, it is much more practical to enforce a contractual condition of this sort in online markets, where economic agents are already routinely tracking the prices of competing offers algorithmically. An OTA can rather effortlessly check whether the prices the partner hotels charge to buyers via its platform are higher than the prices the same hotel charges on competing platforms and on the hotel's own websites.

It follows that a retail MFN obligation is materially different not only from other

\footnotetext{
${ }^{23}$ More precisely, the 'best price' clause employed by HRS and investigated in the context of the German proceedings obliged the partner hotels to always offer on the booking platform the hotel's lowest room price (inclusive of all taxes, such as VAT, city tax, etc.), alongside maximum room capacity, and the most favourable booking and cancellation conditions available on other booking and travel platforms on the Internet. Moreover, the partner hotels could not offer cheaper hotel rates and better conditions via the hotel's own websites - and, after January 2012, to customers direct via telephone sales and at the hotel's front desk. Instead, the "availability guarantee" only applied across platforms, the hotel remaining free to make rooms directly available to customers (via hotel's own website, by telephone, and face-to-face, at the hotel's reception) that were not available on any other platform. Similarly, Booking's standard contracts investigated first by the French, Italian Swedish NCAs contained the hotel's obligation to offer the same or a better price for a room via Booking compared to the price offered by the hotel's own sales channel, both online (website, apps, etc.) and offline (telephone sales and at the hotel's front desk) or via another competing online travel agency and other online and offline intermediaries. The same applied to different conditions with respect to the room or the booking, for example cancellation rules or inclusion of breakfast in the room price. Furthermore, the contracts contained terms obliging hotels to provide Booking with access to the same or a greater number of rooms as provided to Booking's competitors and other third parties. As in the case of HRS, availability parity only applied across platforms (and other distribution channels). Finally, with regard to Expedia, the Italian NCA, whose proceedings involved both Booking and Expedia, did not mention any difference in the substance of the MFN clauses practiced by these OTAs.

${ }^{24}$ In the offline world, a narrow retail MFN clause between a supplier and a shopping mall (i.e. a physical marketplace) would establish, for instance, that a supplier cannot price below what it charges for its products at the shopping mall in any of the supplier's own high street shops.
} 
vertical restraints in general 25 , but also from another type of most favoured nation clause with which competition authorities are already much more familiar. ${ }^{26}$ A mostfavoured-customer clause (MFC) embodies the seller's promise to treat a specific buyer at least as favourably as any other party in an analogous position, i.e. as the seller treats her most-favoured customer. Unlike the retail MFN clauses discussed in this paper, these agreements set identical prices across different buyers rather than across different sales channels (or outlets). Typically, MFC clauses are employed in markets for intermediate goods, and warrant that the buyer at a certain stage of the supply chain will pay a specific input no more than any other customer of the same supplier (called also 'wholesale' MFN clause). ${ }^{27}$ Whereas a MFC clause ensures that the buyer does not pay more than any competitor for the same products or services, a retail MFN agreement dictates rate (price) parity among platforms and other sales channels.

\subsection{Anticompetitive Effects of Retail MFN clauses}

We have seen in the previous subsection that retail MFN clauses, both wide and narrow, affect the relative level of the price that the hotelier charges to the final consumer via the online booking platform, insofar as the room price set by the hotelier for the partner platform is conditioned on the room price displayed on competing platforms and/or on hotel's own channels. This introduces a legally binding

\footnotetext{
${ }^{25}$ See ICN (2015), supra note 11, p. 66 ("A new form of vertical restraint between suppliers and online platforms has emerged in online markets"). While platforms act as intermediaries and not as typical retailers, retail MFN clauses have a clear vertical dimension in the sense that the parties involved operate at different levels of the value chain (in this respect, of course, the use of the term 'retail' is also rather misleading). At any rate, who is the 'buyer' and who the 'seller', who is 'upstream' and who is 'downstream' largely depend on the specific circumstances of the case under analysis.

26 Some MFN clauses that have attracted the attention of competition policy enforcers concerned the sale of turbine generators, of lead-based anti-knock gasoline additives, of synthetic substances belonging to groups of vitamins, the distribution of digital music, of gas, and were found also in dental plan contracts between dental care service providers and dental practices and in healthcare contracts between a health insurance provider and hospitals

${ }^{27}$ For instance, a brewer agrees with a bottle maker that if the bottle maker cuts the price of bottles to any other brewer, the MFC beneficiary will have the price difference refunded. If the bottle maker wants to grant a price discount to any of her brewer-customers, she will therefore need to apply the same discount to the brewer covered by the MFC clause. In this respect, a MFC clause raises the bottle maker's cost of cutting prices. The economics literature has identified some potentials for competitive harms deriving from what has been called an effective 'tax' or penalty on discounting, see J. Baker and J. Chevalier, The Competitive Consequences of Most-Favored Nation Provisions, Antitrust, 27(2), 20 (2013), p. 23. If the MFC beneficiary, however, accounts for a small fraction of the MFC grantor's overall sales, discounting is not likely to be deterred because considered too costly.
} 
horizontal element into the vertical agreement between the OTA and the hotelier. ${ }^{28}$ Moreover, a wide retail MFN clause amounts in practice to the strict implementation of minimum sale prices, as the hotelier must ensure that the room price displayed on the partner platform (the minimum retail price) is not undercut by competing platforms, by third party distribution channels, and by the supplier's own online and offline direct offerings to prospective travellers.

It is not surprising, therefore, that NCAs in the EU and beyond ${ }^{29}$, are considering with great attention the retail MFN clauses commonly employed in a number of digital markets. ${ }^{30}$ The assessment, however, poses significant challenges such as, first, that what we have learned in more than one hundred years of competition enforcement about the typical relationship between supplier and retailer could be of only limited help when online platforms are involved. Second, while the mighty platforms of the digital economy have no say in the suppliers' (users) pricing decision, they are separate legal entities which have very little in common with the typical passive 'agent' under competition law. Third, and related, online platforms invest substantially in demand-enhancing features. Fourth, as mentioned above, there is a complex interplay between the vertical supplier/platform relationship on the one side, and the horizontal element of the price matching promise, on the other. Fifth, the vertical element of the retail MFN clause (i.e., the price control exercised by the supplier) looks suspiciously similar to (de facto) resale price maintenance ${ }^{31}$, which is considered a restriction by object under EU competition law. Sixth, it can be quite difficult for competition authorities to gain an in-depth understanding of the

\footnotetext{
${ }^{28}$ Cfr. A. Fletcher and M. Hviid, Retail Price MFNs: Are they RPM "at its worst?", CCP Working Paper 14-5, 2015.

29 See in particular the detailed decision issued by the Swiss Competition Authority, Wettbewerbskommission, Booking, HRS, Expedia, Verfügung, 19 October 2015, available at https://www.weko.admin.ch/dam/weko/de/dokumente/2016/02/online-

buchungsplattformenverfuegungvom19oktober2015.1.pdf.download.pdf/onlinebuchungsplattformenverfuegungvom19oktober2015.pdf.

${ }^{30}$ Besides the online hotel booking market discussed here and the UK and German investigations into Amazon's marketplace, the European Commission in June 2015 opened a formal investigation into parity obligations contained in Amazon's contracts with publishers, see EC Press Release, 11 June 2015, available at http:/ / europa.eu/ rapid/press-release_IP-15-5166_en.htm.

${ }^{31}$ Fletcher/Hviid (2015), supra note 28.
} 
peculiarities of the business models under which online platforms operate, especially against the background of rapidly changing market scenarios.

Despite theoretical and empirical challenges, the NCAs involved in the online hotel booking cases, conforted by recent economic analysis ${ }^{32}$, agree that retail MFN clauses in principle can produce an array of anticompetitive effects. It should be highlighted, however, that while the findings of the German NCA are contained in a formal decision and, at least in the HRS case, already confirmed by the judiciary ${ }^{33}$, the triad of NCAs investigating Booking have merely assessed the platform's commitments and therefore their competition decisions do not contain any definite findings on the existence of an infringement. Still, these decisions, taken together, provide rather suitable guidance in explaining whether and how this type of vertical arrangements can be infringing Art. 101(1) TFEU. ${ }^{34}$

Much in line with mainstream economic theory, there were two types of likely anticompetitive effects of rate parity that were broadly acknowledged by all four competition authorities, namely softening of competition (a) and entry foreclosure (b). The assessment of narrow MFNs, instead, was much more controversial (c).

a) Softening of competition

Under retail MFN clauses, OTAs have little incentive to compete among themselves by offering better (lower) CPA fees. ${ }^{35}$ An OTA benefiting from a retail MFN can raise the commission fees it charges to hotels with little fear that the hotels might retaliate by increasing the advertised prices on the OTA relative to the prices advertised on

\footnotetext{
32 LEAR (2012), supra n. 22; see also the in-depth literature overview prepared for the recent OECD Hearing on Across Platform Parity Agreements: M. Hviid, Vertical Agreements Between Suppliers and Retailers That Specify a Relative Price Relationship Between Competing Products or Competing Retailers, 27-28 October 2015, available http://www.oecd.org/officialdocuments/publicdisplaydocumentpdf/?cote=DAF/COMP(2015)6\&d oclanguage $=\mathrm{en}$.

33 OLG Düsseldorf, supra note 6.

${ }^{34}$ Further guidance is offered by the results of the UK inquiry with regard to retail MFN clauses in the private motor insurance sector, see in particular Competition Commission, Private Motor Insurance Market Investigation: Provisional Findings Report (2013), available at https://assets.digital.cabinetoffice.gov.uk/media/5329dec5ed915d0e5d00029f/provisional_findings_report.pdf.

${ }^{35}$ LEAR (2012), supra n. 22, p. 99 ff.; Autorité de la concurrence, Booking.com, § 116; Bundeskartellamt, HRS, § 60, § 156; OLG, HRS, § 107; Autorità della Concorrenza e del Mercato, Booking.com, § 7; Konkurrensverket, Booking.com, $\$ 21$.
} 
competing platforms and/or other sales channels. Conversely, OTAs under rate parity have less incentives to lower commission fees.

The core argument highlighting this type of anticompetitive effect is rather intuitive. The Autorité de la concurrence explains that this softening of competition occurs because of what can be called a dilution (thinning-out) mechanism. ${ }^{36}$ For example, one double room in the Parisian hotel X for the $19^{\text {th }}$ November $2016^{\text {"gross" }}$ price is 200 Euro and the commission fee paid to the OTA is $18 \%$. Pursuant to the rate parity obligation, if the OTA decides to raise the commission fees by $2 \%$, hotel $\mathrm{X}$ is practically prevented from increasing the room's retail price as advertised on the now more expensive OTA by an amount that entirely covers the commission fee's increase. In fact, if hotel X raises the room's rate displayed on the more expensive OTA, it has to increase the published rate on all other sales channels covered by the retail MFN clause. Instead, in the absence of a retail MFN, a platform is likely to be constrained in the commission fee it charges to hotels by the fear that a higher fee would lead to higher hotel room prices displayed on its own platform and therefore to a potential loss of market share relative to competitive sales channels. In this respect, retail MFN clauses sever the link that normally exists between the price asked by a market actor and the demand addressing the same market actor. Overall, competition among platforms is "dampened ${ }^{37 "}$ in the absence of an explicit agreement: there is less incentive to reduce commission fees, as there is less incentive not to raise them.

b) Entry foreclosure

Retail MFNs may also foreclose the entry of efficient, innovative OTAs into the market. To see this, imagine that an OTA wishing to enter the market is willing to offer lower commission fees to its hotel partners, in the hope that hotels will be offering lower hotel room prices to consumers, and, as a consequence, the platform will grow its trade volume. However, this specific entry strategy envisaged by the more cost effective OTA is bound to fail because the hotelier wishing to discount its rooms on the entrant's platform needs to offer that same discount to consumers shopping on all

\footnotetext{
36 Autorité de la concurrence, Booking.com, § 117.

37 See Baker and Chevalier (2013), supra n. 27.
} 
other platforms and sales channels under a rate parity obligation. ${ }^{38}$ In this regard, competition authorities stress that the foreclosing effect is strengthened by the fact that the lion's share of the relevant hotel portal market is covered by MFN clauses, as the MFN agreements of HRS, Booking and Expedia cover almost the entire market. ${ }^{39}$ Moreover, the foreclosure effect here can be particularly serious considering the presence of so called indirect network effects. The literature on two-sided markets explains that a platform entering the market must attract a critical mass of both suppliers and customers (chicken-egg problem) if it wants to succeed. ${ }^{40}$ The retail MFN clause makes it practically impossible for the new platform to adopt an aggressive, low-price commercial strategy, because hotels cannot charge lower prices on the new platform. ${ }^{41}$

The argument could be made, however, that under retail MFN a small or new entrant can offer to its own customers room rates that are as 'good' as the ones offered by established platforms and that this could facilitate market entry. While competition between OTAs on the level of commission fees is hampered, platforms would still compete by engaging in non-price marketing strategies, such as investing in brand recognition and online visibility. The Autorite de la concurrence notes though that it would be very difficult for a small platform or a new entrant to compete on these nonprice based terms with established OTAs. In particular, incumbent OTAs invest massively into online advertising. Instead, if OTAs were able to compete on the level of commission fees, a small or new OTA could acquire immediate online visibility through its offering of convenient room rates, in particular as listed by metasearch engines.

Not only cost-effective, but also innovative OTAs are prevented from entering the market because of retail MFN clauses. Better ideas, marketing tools and technology could further reduce users transaction costs, and provide final customers with more

\footnotetext{
${ }^{38}$ Cfr. LEAR (2012), supra n. 22, p. $98 \mathrm{f}$.

${ }^{39}$ Bundeskartellamt, HRS, § 174; Autorité de la concurrence, Booking.com, § 129; AGCM, Booking.com, § 8; Konkurrensverket, Booking.com, § 22.

40 B. Caillaud and B. Jullien, Chicken \& egg: competition among intermediation service providers, RAND Journal of Economics 34(2) (2003), pp. 309-328.

${ }^{41}$ See Autorité de la concurrence, Booking, § 125.
} 
attractive deals. ${ }^{42}$ Retail MFN clauses prevent hoteliers from rewarding more innovative platforms by agreeing on a different pricing model, thus reducing the incentives for incumbents and entrants to innovate. For instance, a specific OTA could be in a position to offer quality-based innovations to hotels, and this would justify a lower price for consumers using that platform than if they used another platform. Such innovation would enable lower hotel prices to be offered on that platform, reflecting the cost savings and the other benefits to the hotelier due to the platform's innovation, with the prospect of generating more sales for the platform. However, if the hotels cannot offer cheaper hotel rooms via innovative platforms because of the existence of retail MFN obligations with well-established platforms, this would reduce the incentive for a platform to innovate as the platform could not receive a greater market share from offering cheaper hotel rooms relative to its competitors. Hoteliers could still reward innovative platforms with higher commission fees in exchange for a better quality, but this would not lead to increased trade volumes and a higher platform's market share. Put differently, the benefits of the platform's innovation could be passed on to the hotel partners, possibly, but not to final consumers.

\section{c) The Anticompetitive Effects of Narrow Retail MFN Clauses}

The two types of negatives effects considered above, chiefly affecting competition among OTAs (i.e. intrabrand), were recognised by all four competition authorities. Instead, national NCAs did not present a united front on two other major issues, namely the effects of rate parity on interbrand competition and the likely competitive implications of narrow retail MFN clauses in particular. As regards the first issue, possible anticompetitive effects of rate parity beyond intrabrand restrictions were acknowledged only by the German NCA. ${ }^{43}$ Whereas the hotels under rate parity control the price of the rooms they offer, they cannot adjust those prices flexibly in reaction to differences in the costs of using alternative distribution channels, their own

\footnotetext{
42 The Bundeskartellamt mentions that the platforms (applications) JustBook and BookitNow regarded their access to the market as being hindered by the MFN clauses employed by HRS, see Bundeskartellamt, HRS, \& 235. The CMA identifies at least one instance in which entry into the price comparison websites (PCWs) market was prevented by the presence of retail MFNs, see CMA, Private motor insurance market investigation, Final report (2014), available at https://assets.digital.cabinetoffice.gov.uk/media/5421c2ade5274a1314000001/Final_report.pdf, §§ $8.69 \mathrm{ff}$.

${ }_{43}$ Bundeskartellamt, HRS, p. $59 \mathrm{ff}$.
} 
included, or to changes in the broader competitive landscape. According to the Bundeskartellamt, this negatively affects interbrand competition among hotels.

As mentioned in the Introduction, the NCAs' split on the second issue was fraught with far-reaching consequences. As of July 2015, Booking amended its rate parity clauses according to the commitments with the triad of competition authorities. While narrow MFN was still in place for online reservations on the hotel's own website and and other similar sales channels, price and conditions parities were no longer demanded for offline reservations (at the hotel reception, via phone/e-mail, via a travel agency, etc.). Moreover, hotels were allowed to offer more favourable terms to their loyalty programme customers and to other customers provided that these discounts are not marketed and advertised online to the general public.

However, according to the German NCA, even narrow retail MFN clauses with such a reduced scope would significantly limit hotels' incentives to grant better rates to individual hotel portals in exchange for lower commissions from OTAs. The reason for this is that hotels would want to prevent a so called cannibalization effect, that is the negative impact of online sales via OTAs (under rate parity) on the hotels' own more profitable sales channel. In other words, hotels would not grant better rates to specific OTAs if this had substantial adverse consequences to the competitiveness of the direct online channel and their overall profitability.

Consider again that narrow retail MFNs do not prevent in principle hotels from displaying different prices on different OTAs and competition between OTAs for market share should lead them to seek to list the best hotel rates, putting pressure on CPA fees. A narrow retail MFN clause merely requires a hotel's own-website room rate to be higher than, or equal to, the room rate displayed on the partner OTA. In other words, a narrow MFN prevents the hotel's direct channel from undercutting the OTA.

At the same time, however, the hotelier wants to maintain the competitiveness of the rooms distributed through its direct sales channel because these are the most profitable sales (no commission is paid). Let's imagine that OTA1 requires a commission fee of $18 \%$, OTA 2 of $15 \%$ and OTA3 of $16 \%$, whereas the distribution cost 
via the hotel's own website is 5\%. Given the same "gross" room price of 100, therefore, if would be expected that, without rate parity, the price displayed on OTA1 would roughly be 118, on OTA2 115, on OTA3 116, and on the hotel's direct channel 104. If the hotel agrees a narrow MFN clause with OTA1, this prevents the hotel offering the same room via its own website for less than 118. As a consequence, in order to avoid cannibalization of its online online direct channel, the hotel will set prices on competiting OTA2 and OTA3 to be at least equal to the price on the OTA1. In this respect, a single narrow retail MFN between a hotel and an OTA imposes a floor price for hotel's rooms on any OTA that is equal to the hotel's website price, just as a wide retail MFN would. In this respect, any OTA benefits from every single narrow MFN that is entered into across the online hotel booking market, regardless of whether the OTA is a party to that MFN (network effect ${ }^{44}$ ).

While also the French, Italian and Swedish NCAs recognise the relevance of the cannibalization effect ${ }^{45}$, views between them and the German NCA differ, basically, as to the impact on the analysis of actual hotel's share of sales via the hotel's own channel. It is not disputed that hotels' incentives to offer a lower price via an OTA than in the hotel's own channel in principle increase if the share of sales not covered the narrow retail MFN clause decreases. As the NCAs triad finds that this applies only to a small number of hotels in their respective geographical market, it is estimated that the cannibalization effect remains limited. ${ }^{46}$

Instead, the German NCA, based on a more dynamic reasoning supported by the results of a hotel survey conducted in June $2015^{47}$, convincingly concludes that the risk that price parity between online travel agencies will continue to apply in practice cannot be seen as effectively removed.48 The Bundeskartellamt considers that the

\footnotetext{
${ }^{44}$ Competition Commission (2013), supra note 34 §§ $9.41 \mathrm{ff}$.

${ }^{45}$ See Autorité de la concurrence, Booking, $\S \S 302 \mathrm{f}$.

46 Ibidem.

47 Apparently, based on the results of this survey, the German NCA changed the opinion previously expressed in the HRS decision that hotels' own websites were (still) largely irrelevant as distribution channel with respect to the largely small and medium-sized hoteliers in Germany, see Bundeskartellamt, HRS, § 204.

${ }^{48}$ Moreover, the anti-competitive effects of narrow MFN are strengthened by other clauses in the contracts with Booking relating to minimum availability and the best price guarantee, see Bundeskartellamt, Booking, §§ 217-219.
} 
online direct channel (with real-time booking option) is increasingly crucial for hotels ${ }^{49}$, and for certain hotels around half of their online bookings already comes via their own websites. ${ }^{50}$ Moreover, it cannot be excluded that, if only a relatively small share of hotel sales is actually covered by the narrow retail MFN clause, this should be seen (also) as a consequence of the broad application of rate parity by OTAs in the recent past. As the hotel's own online presence could never be the cheapest distribution channel, especially small and medium hotels had very few incentives to invest in developing and improving it. ${ }^{51}$ Finally, it should also be noted that rapid innovations in ICT technologies and related business models make the real-time booking option increasingly convenient and promising for hotels.

Similarly, under limited rate parity, market entry by more cost-effective OTAs would be more unlikely. ${ }^{52}$ If an entrant, low-commission OTA wished to display cheaper hotel rooms than the incumbent OTAs, hotels under retail MFN would generally not wish to encourage it, because the obligation requires them to maintain their direct sales price above the price on the entrant OTA and that would take sales away from their own, increasingly important direct channels. Thus, low-commission-fee entry would be significantly discouraged, much as it happens under wide MFN clauses.

\subsection{The Free-Riding Defence}

Confronted with the serious allegations of anticompetitive behaviour seen in the previous subsection, the OTAs involved in the proceedings before the national competition authorities in the EU emphasize in their defence the increased risks of free-riders they are facing in a transparent environment such as the Internet. ${ }^{33}$ OTAs, as seen above, provide services to connect buyers and sellers for mutually advantageous transactions and charge CPA fees for their services. If the parties consummate the exchange off of the platform and avoid the transaction fees, this

\footnotetext{
49 Three main reasons for this: price structure, easier customer service, and platform-incompatibility of some marketing formats preferred by some hoteliers, ibidem $\S \S 196 \mathrm{f}$.

50 Ibidem, § 194.

51 Ibidem, § 195.

52 Ibidem, §§ 220-223.

53 Bundeskartellamt, HRS, § 199; Autorité de la concurrence, Booking, § 64 ; Konkurrensverket, Booking, $\S 29$.
} 
potentially affects investments into the platform. The OTAs involved in the proceedings therefore argue that MFN clauses enable the platform to make investments that benefit the hoteliers without facing the risk that the latter will opportunistically refuse to bear the costs of these investments after they have been made. It should be noted in this regard that it is hardly the first time that this type of defence is invoked in a competition proceeding involving multi-sided platforms. ${ }^{54}$ In fact, it is generally accepted that the traditional efficiency justifications for vertical restraints might apply to multi-sided platforms as well. 55

The special form of free riding investigated in the online hotel booking cases is the socalled hold-up problem. In this context, MFN clauses could be used to induce investments in situations in which there is a form of vertical externality ${ }^{56}$ that derives from independent decisions on investments. ${ }^{57}$ If an OTA invested in advertising the hotel's room on its platform, but consumers discovered that the hotel rooms offered on the OTA were available cheaper if booked directly with the hotel, consumers might use the services offered by the platform but not book the hotel room through the OTA (also called risk of disintermediation ${ }^{58}$ ). In fact, the cost of staying at a specific hotel can easily be compared on the Internet once the hotel has been chosen. The hotel, selected on the platform and contacted by the customer directly, would then be able to offer a better price than the one displayed on the platform's website because the hotel would be bypassing the platform fee. Crucially, the Internet user could find the website of

\footnotetext{
${ }^{54}$ See, for instance, Groupement des Cartes Bancaires v Commission, C-67/13 P, EU:C:2014:2204; United States v. Am. Express Co., 2015 WL 728563, at 6 (E.D.N.Y. Feb. 19, 2015).

${ }_{55}$ D. Evans, Economics of Vertical Restraints for Multi-Sided Platforms, University of Chicago Institute for Law \& Economics Olin Research Paper No. 626 (2013), p. 12 and Fn. 23, available at http:/ / papers.ssrn.com/sol3/papers.cfm?abstract_id=2195778

${ }^{56}$ An externality arises whenever a party making a decision does not take (full) account of the decision's effects on other parties. An externality is vertical when it affects undertakings at different levels of the value chain.

${ }^{57}$ Rather than from independent decisions on linear pricing, see P. Davis and E. Garcés, Quantitative Techniques for Competition and Antitrust Analysis, Princeton University Press, Princeton (2010), p. 507 ("Double marginalization ...can be understood as a vertical pricing externality").

58 See A. Hagiu and J. Wright, Multi-sided Platforms, Harvard Business School Working Paper 12-024 (2011), pp. 28-29; ICN (2015), supra note 11, p. 6.
} 
the hotel that it previously selected on the OTA without significant investment from the hotelier in terms of Internet visibility. 59

It is well-known that the free-riding defence is one of the pillars of the so called more economic approach in competition policy. Economic theory explains, in fact, that individual undertakings producing complementary goods or services can experience coordination failures. Where a retailer provides valuable pre-sale services, for instance, consumers are likely to buy extra units on which the manufacturer earns a margin. Moreover, pre-sale services that boost the demand for a product can also benefit other distributors of the same product. The retailer, however, may decide not to provide pre-sale services that consumers value if this decision does not increase the retailer's own profits, despite an increase in the profits jointly earned by the manufacturer and the retailer. Specifically, the retailer may desist from committing to those investments in the anticipation of a free-riding risk, namely that consumers may enjoy the retailer's pre-sales services but subsequently buy the products from cheaper sources. ${ }^{60}$ Concisely put, the risk is that other undertakings could cash in on the retailer's efforts to provide pre-sale services.

The yeast of the paradigmatic free-rider scenario, in which an undertaking such as a retailer does not reap the full benefits of the efforts she provides to consumers, is that her efforts are likely to be underprovided. Recognising this, undertakings along the value chain could engage in more sophisticated contractual relationships than simple spot arrangements, providing suitable economic incentives to exert the required level of sales effort. ${ }^{61}$ Along the same lines, courts and other competition law enforcers have long recognised that vertical restraints may remedy this type of market imperfection. Absent suitable provisions between retailers and manufacturers, services that enhance

\footnotetext{
${ }^{59}$ Instead, a competing OTA would have to incur significant investments in order to gain Internet visibility. This argument would of course be relevant if a horizontal free-riding problem were at issue in the investigation.

${ }^{60}$ Typical examples of free rideable services are presale onsite services such as retailer demonstrations, consumer education, special showrooms, product testing, etc. Thus, for example, pure Internet players could free-ride on the services provided by traditional 'brick and mortar' stores.

${ }^{61}$ L. Telser, Why Should Manufacturers Want Fair Trade? 3 J.L. \& Econ. 86 (1960); B. Klein and A. Lerner, The Expanded Economics of Free-Riding: How Exclusive Dealing Prevents Free-Riding and Creates Undivided Loyalty, 74 Antitrust L.J. 473 (2007); H. Marvel and S. McCafferty, Resale Price Maintenance and Quality Certification, 15 RAND J. Econ. 346 (1984).
} 
interbrand competition might be underprovided because discounting retailers can free-ride on retailers "who furnish services and then capture some of the increased demand those services generate". ${ }^{62}$

In the scenario analysed by competition authorities in the online hotel booking cases, new bookings are likely to generate revenues for both the hoteliers (room price) and the platform (commission fee). The specific effort exerted by the platform can be the most efficient way to increase bookings, such as providing good search capabilities and satisfactory client support. Despite being an intermediary, the overall quality of the good or service provided to consumers can well depend in a significant way on inputs provided by the platform, i.e. an undertaking that, together with the hotelier, has a direct relationship with the consumers. However, since the platform will only take into account its own benefits when choosing the level of the service efforts provided, the level is likely to be suboptimal. If the costs of the service are borne solely by the OTA, it may not be willing to invest in sales efforts that accrue also to the hotel and on which the hotel makes a positive margin.

In this context, a retail MFN clause could stop hotels from free-riding on the platform's investment, because hotels would be prevented from selling at lower prices direct to customers. The probability that an OTA is used for search but is not the recipient of the commission fee (and therefore of the possibility to recoup the platform's investment) is lower if the chance of finding the same product cheaper on the hotel's website is excluded, as would be the case with a narrow MFN in place. Platforms therefore argue that possible higher prices and other anticompetitive effects allegedly produced by retail MFN in the end do not harm consumers, as the practice is necessary to generate services that most consumers judge to be beneficial to them and which could not be provided in a less wasteful way.

Despite finding the free-riding defence plausible at first sight ${ }^{63}$, in the two separate decisions involving HRS and Booking respectively, the German competition authority concluded that there was insufficient evidence of the efficiency gains of retail MFN

${ }^{62}$ Continental T.V.v. GTE Sylvania Inc, 433 U.S. 36, 55 (1977).

${ }^{63}$ See German contribution to the OECD Hearing on across platform parity agreements (2015). 
clauses. ${ }^{64}$ In particular, efficiencies were likely to be small compared to the anticompetitive effects revealed in the course of the Bundeskartellamt's investigation. Instead, the French, Italian and Swedish competition authorities considered that in the total absence of rate parity there would be a real risk of free riding in the online hotel booking sector. ${ }^{65}$ The remaining parts of this article will highlight and discuss some peculiarities and challenges related to the application of the free-riding defence to the narrow MFN clauses practised in the online hotel booking.

\section{The efficiency defence as applied to retail MFN clauses}

According to EU competition law, any vertical agreement that restricts competition may in principle benefit from an exemption under Article 101(3) TFEU, provided four cumulative conditions are satisfied, namely the agreement must contribute to improving the production or distribution of goods or to promoting technical or economic progress, a fair share of the resulting benefits must go the consumers, the restrictions must be indispensable to the attainment of these objectives, and the agreement must not afford the parties the possibility of eliminating competition in respect of a substantial part of the products in question. Article 2 of Regulation $1 / 2003^{66}$ provides that it is for the party claiming the application of the exemption to prove, "by means of convincing arguments and evidence" 67 , that the conditions laid down in paragraph 3 of Article 101 TFEU are fulfilled.

Under the first condition of Article 101(3) TFEU, agreements that may be exempted must '[contribute] to improving the production or distribution of goods or to promoting technical or economic progress'. Whereas the treaty provision does not refer specifically to "efficiencies", the Guidelines on the application of Art.101(3)68 state, rather unequivocally, that the "purpose of the first condition of Article 101(3) is

\footnotetext{
${ }^{64}$ Supra, notes 4 and 10.

65 OECD/France (2015), supra note 12, § 47.

66 Council Regulation (EC) 1/2003 of 16 December 2002 on the implementation of the rules on competition, OJ L 1, 04.01.2003, p.1-25.

67 Cfr. Case 42/84 Remia and Others $v$ Commission [1985] ECR 2545, \& 45;Joined Cases C-501/06 P, C-513/06 P, C-515/06 P and C-519/06 P GlaxoSmithKline Services and Others v Commission and Others [2009] ECR I-9291, § 82.

${ }^{68}$ Guidelines on the application of Article 101(3) of the Treaty (101(3) Guidelines), OJ C 101, 27.4.2004
} 
to define the types of efficiency gains that can be taken into account and subject to the further tests of the second and third conditions of Article 101(3)" (§ 50). The efficiency gains must be objective, i.e. not assessed from the subjective point of view of the parties (§ 49). Moreover, efficiency claims need to be substantiated so that they can be verified, in particular in their size and likelihood (§ 55). Finally, the parties have to prove the causal link between the restraint and the claimed efficiencies. ${ }^{69}$

Importantly, when examining the advantages flowing from retail MFN clauses, and balancing them with negative effects within the framework of Article 101(3) TFEU, competition enforcers have to take into account the two-sided nature of the undertaking under investigation. ${ }^{70}$ The 2010 Guidelines on vertical restraints, however, do not offer any specific guidance concerning the application of the freeriding defence to practices instigated by online platforms. ${ }^{71}$ Moreover, while the competition authorities, the investigated parties and other stakeholders could already rely on some important economic contributions highlighting the likely anticompetitive effects of retail MFN clauses, ${ }^{72}$ the analysis of their possible efficiencies is still much less developed. ${ }^{73}$

\subsection{Efficiency gains and the free-riding problem}

As noted above, eliminating a free-rider distortion is viewed as one of the main categories of efficiency that exempt vertical agreements from prohibition. More specifically, the Guidelines on vertical restraints indicate that, among the principal reasons that may justify the exemption of certain vertical restraints, there is the solution to a free-rider problem, of both horizontal and vertical nature. ${ }^{74}$ First of all, the Commission refers to forms of horizontal free-riding on the promotion efforts of distributors, but also at the level of suppliers investing in promotion at the buyer's

\footnotetext{
${ }^{69}$ Ibidem, § 54 .

${ }^{70}$ Case C-382/12 P, MasterCard and Others $v$ Commission, ECR, EU:C:2014:2201, §§ $237 \mathrm{ff}$.

71 And it is not until 2022 that the revision of the current Block Exemption Regulation on vertical restraints is planned, see Commission Regulation 330/3012, OJ L 102, 23.4.2010, p. 1-7.

${ }^{72}$ See supra Subsection 2.2.

${ }^{73}$ Evans (2013), supra note 55, offers one of the very few analyses of possible efficiencies of vertical restraints in the context of two-sided businesses.

74 VR Guidelines, § 107.
} 
premises. For a genuine free-rider issue to emerge, however, some conditions should be satisfied: 1) free-riding among retailers occurs on promotional services and activities for which the customer cannot be charged individually; 2) the customer does not well know what she wants, as the product or service benefiting from the promotional efforts is relatively new, technically complex, or for which reputation is a major demand factor; 3 ) the product of service must be of a reasonably high value, so as to make worthwhile for a customer to go to a shop for information and to another to buy; 4) it is not practical for the supplier to impose contractual obligation to buyers to provide the required promotional efforts. ${ }^{75}$ Besides expressily mentioning two further, more specific, instances of horizontal free-riding ("open up or enter new markets" and "certification free-riding"), the Commission indicates that the application of certain vertical restraints may be justified also by the solution provided to a vertical free-riding, or hold-up, problem. Client-specific investments by the supplier or the customer could be underprovided unless specific vertical restraints are allowed. For the risk of underinvestment to be real or significant, however, some conditions must be fulfilled: 1) the investment is relationship-specific; 2) the investment is long-term and cannot be recouped in the short run; 3) the investment is asymmetric in the sense that one party to the contract invest more that the other party. When these conditions are met, a vertical restraint may be justified for the duration necessary to depreciate the investment.

When putting forward a free-riding defence, the parties should therefore demonstrate that the vertical restraint achieved the objective efficiencies of solving a genuine, and relevant, free-riding problem. This is conditional on two main variables, i.e. the magnitude of the investment made by the online platform in order to increase demand (a) and the likelihood that the investment will be free-ridden (b).

\footnotetext{
${ }^{75}$ Moreover, a footnote to the text referring to the general free-riding problem mentions an estimate of welfare benefits to new customers who did not previously have sufficient information to make an informed choice relative to already informed customers. In other terms, aggregate consumer welfare may be reduced despite higher levels of promotional activities and greater output, and this is part of the analysis to be conducted under Article 101(3) TFEU, see VR Guidelines, Fn. 38.
} 


\section{a) OTAs' investments}

A free-rider problem can only exist when there is something on which to free-ride. Arguably, the OTAs involved in the recent rate parity cases invest substantial amounts of resources in expanding the services offered to both consumers and hoteliers, as they need to increase demand on both sides of the market ("to get both sides on board"). In other terms, both groups, or populations, of the customer base are crucial to the platform. ${ }^{76}$

In the online hotel booking cases, competition authorities identified three main categories of investments made by OTAs, i.e. investments aimed at improving the profile of the hotel establishment on the platform's website, at increasing the functionality of the OTA, and at promoting the online visibility of the platform.

The first category consists of promotional activities to which the OTA is contractually bound with the hoteliers. The platform curates hotel descriptions (providing tools for text-editing, for enhancing the visual presentation or appearance of the hotel, etc.), produces translations of the hotel descriptions in a number of foreign languages, makes available customer services via local teams responsible for managing the relationship with the hotels, etc. ${ }^{77}$ These investments may well be sunk insofar as they cannot be used for the distribution of accommodation services of other hotel companies. ${ }^{78}$ However, according to the evidence gathered by the Bundeskartellamt both in the HRS and the Booking investigations, these one-off activities carried out by the platform are not particularly costly. The German NCA points out in this regard that the average annual commission income that HRS earns per hotel is substantially larger than HRS's one-off expenditure per hotel, and the platform is therefore able to

\footnotetext{
${ }^{76}$ See D. Evans, The Antitrust Economics of Two-Sided Markets, Yale Journal on Regulation 20(2) (2003), p. $325 \mathrm{ff}$. Besides platform's investments on both sides, it should be noted that very often at least one user group is also required to make some sort of investments in order to join a platform, such as for instance in order to acquire the technical knowledge necessary to develop chat bots for a specific messaging app.

77 Bundeskartellamt, HRS, § 204: Autorité de la concurrence, Booking.com, § 18, Fn 36. Thus, the HRS website explains that, among other things, hotel descriptions are translated into more than ten languages and that more than 300 HRS experts worldwide stand aside and support hotels optimizing their online presence, see http://www.hrs.com/web3/showCmsPage.do?clientId=ZGVfX05FWFQ\&cid $=49-3 \&$ pageId $=$ partner.

78 See VR Guidelines, § 107.
} 
recoup its relationship-specific investments even if the parties decide to terminate the contract upon completion of just one year. ${ }^{79}$

Moreover, OTAs undertake non-contract-specific investments aimed ad improving the usefulness and utility of the platform, such as optimizing the search functions and increasing trust by platform users (e.g., making available tools for online review and providing individual support to booking customers).

The third and by far more substantial category of investments made by OTAs, however, is targeted towards the promotion of the overall visibility of the platform, and consists mainly of advertising and marketings expenditures aimed at increasing the general awareness about the specific OTA and attracting users to the platform. Allegedly, these considerable expenditures can be explained considering the gatekeeper's role to the Internet played by horizontal (general) search engines (e.g. Google, Bing, etc.) and travel-specific metasearch engines (e.g. Skyscanner, Tripadvisor, Trivago, Kayak or Google Hotel Finder etc.). Thus, in order to gain online visibility, OTAs invest significantly in bidding search keywords such as "hotels in Trento" and "Hotel Accademia" (so called name bidding - or grabbing). ${ }^{80}$ Moreover, OTAs make substantial pay-per-click (PPC) payments to metasearch engines. For instance, Booking indicated that its PPC expenses for Google and metasearch engines in Germany constituted between [30 and 60]\% of its German commission revenue from bookings issued from PPC advertising on those online platforms. ${ }^{81}$

b) Are Platform's investments subject to free-riding?

Whether the investments made by the platform are subject to free-riding by other market participants is the second factual element to be assessed with a view to substantiating this type of efficiency gains. OTAs maintain that investments

\footnotetext{
${ }^{79}$ Bundeskartellamt, HRS, § 204; Bundeskartellamt, Booking, § 276. Moreover, the hotels often provided OTAs with pictures, videos and descriptions themselves.

${ }^{80}$ Via Adwords bidding and other forms of online advertising, the major OTAs alone contribute to an appreciable extent to Google's overall advertising income, see Wall Street Journal, Google Checks In to the Hotel Business, April 8, 2014 ("Online travel agencies are among Google's biggest advertisers. Priceline Group will spend more than $\$ 1.5$ billion in 2014 on Google advertising and Expedia could spend another $\$ 1$ billion, mainly to attract hotel bookings").

81 Bundeskartellamt, Booking, § 277.
} 
enhancing the quality of their services, and intensifying the quality dimension of competition among platforms, would be recovered only insufficiently as a result of the lower room prices offered directly by hotels. Deprived of the protection granted by rate parity, OTAs' investments would not be compensated for by adequate commission earnings.

At first glance, the likelihood of free-riding by hoteliers is very high. As discussed above, hoteliers set themselves the room rates displayed on the platform. It follows that a hotelier could easily divert visitors from the OTA to its own website by undercutting platforms on price, i.e. by decreasing the sale price of the rooms displayed on the hotel's own sales channel. A broader and more in-depth look, however, reveals that the real extent of the free-riding problem is much more uncertain.

First, it is important to understand on what exactly hoteliers would be free-riding. Thus, hoteliers could benefit from some services and tools provided by the platform and aimed at increasing online visibility and attraction, such as advertising and marketing, alongside web and mobile analytics derived from the large troves of data collected by the OTAs in their intermediary's capacity. Similarly, hoteliers could be free riding on the platform's image and branding. In this respect, OTAs have been claimimg that, simply by being displayed on the platform, hotels would benefit from a "halo", "billboard" or "showrooming" effect, causing a significant increase of direct bookings. ${ }^{82}$ However, this reasoning seems to assume that OTAs represent a predominant source of information about hotel companies for prospective guests, while in reality there are countless ways the "customer journey" starts off and moves on (blogs, articles in on- and offline newspapers and reviews, meta search engines, friends, etc.). It is equally important to note that being displayed on the online booking

${ }^{8282} \mathrm{Cfr}$. C. Anderson, The billboard effect: Online travel agent impact on non-OTA reservation volume, Cornell Hospitality Report, 9(16) (2009) and further studies by the same Author sponsored by Expedia. A more recent survey sponsored by a US hotel association arrives at totally different results, see Tnooz, The Billboard Effect is dead, says a study of hotels listed on OTAs, 30 July 2015, available at https:// www.tnooz.com/article/the-billboard-effect-is-dead-says-a-study-of-hotels-listed-on-otas/. The Swiss competition authority notes that the alleged billboard effect, at least with regard to the national hospitality market, is manifestly contradicted by the facts, see Wettbewerbskommission, Booking, HRS, Expedia, supra note 29, § 380. 
platform does not necessarily indicate that a hotel is a preferred establishment, has a high level customer service, or is of outstanding quality. In fact, OTAs like Booking, Expedia and HRS generally do not decline to list hotels based on the results of any sort of quality screening, so that platform's listing can hardly be seen as an endorsement from which a significant halo effect could eventually emanate. ${ }^{83}$

Second, free-riding has a negative impact on incentives to invest only if the platform is prevented from realistically recovering its expenditure. This means that where investments are low and therefore can be recouped in a relatively short time, as in the case of the contract-specific, promotional, one-off services provided by platforms to hotels, free-riding can hardly be an issue. Along the same lines, investments that can be used profitably in alternative uses are per-se non free-ridable. It follows that OTAs have to prove that their investments in quality services would largely be ineffective due to free-riding. It is definitely conceivable and indeed realistic that, to the extent that hoteliers would be less willing to pay CPC fees to OTAs, and instead preferably make investments in their own online presence, this could somewhat constrain the investments in the quality of the platform's services. According to the German NCA, however, despite some customer leakage, the rationale for OTAs' investments into quality services would not be adversely affected. ${ }^{84}$ In fact, given the importance of indirect network effect in two-sided markets, the overall expenditure in quality services is a crucial competitive variable that is used profitably also outside of specific contracts with hoteliers. Thus, investments into the platform's functionality and convenience of use are an essential qualitative element of the platform's popularity among users, namely both for the travellers' decision to book a room on a specific platform and for the hotels' decision to join a specific platform. ${ }^{85}$ As the constant improvement of the quality of all these specific services is one of the essential

\footnotetext{
${ }^{83}$ Instead, in the case of Tripadvisor, a brand 'halo effect' could be more likely. In fact, hotels blithely display Tripadvisor logos on their premises, own websites, etc., bearing witness to the positive reviews left by platform's users.

84 Bundeskartellamt, HRS, para. 207; Bundeskartellamt, Booking, para. 267. Similarly, the Düsseldorf Higher Regional Court upholding the Bundeskartellamt decision concluded that it would be in the OTA's commercial interest to improve its market position through investment in quality, special offers and promotional activities. In fact, the more users a platform attracts, on both the supply side and the demand side, the more appealing it becomes for new users in turn, see OLG, HRS, para. 188.

85 Bundeskartellamt, HRS, § 207.
} 
characteristics of online platforms, there are distinct incentives for the OTAs to continue investing in them. Interestingly, without the protection afforded by rate parity, OTAs may even choose to increase their investments with regard to the platform's overall attractiveness and convenience of use, as this could make prospective travellers more resistant to the temptation of switching to competing sales channels and book there. ${ }^{86}$

Third, genuine free riding arises only where the hotelier gets something for free instead of having to pay for it. In so far as some prospective travellers are attracted to the OTA's website because of the valuable overview of the commercial propositions made available by hoteliers directly, the data so generated can have economic value for the platform (e.g., online advertising, trend analysis, etc.) despite ensuing consumer leakage to other sale channels. In a similar vein, even bidding on keywords that refer to specific hotels (e.g., "Hotel Accademia Trento") dovetails nicely with the platform's interest, as it is an effective means of attracting prospective travellers to the platform's website, where they are likely to be subject to all sorts of discrete nudges in order to steer users' final choices (e.g., by the often very opaque ways in which rankings of search results are presented, by fine-tuning visual enhancements of website pages, etc.), also quite away from consumer's initial preferences. In this case, it is highly questionable whether the platform invested in keyword advertising with the main intent of helping deliver the consumer to that specific hotel.

Fourth, it is quite clear that investments made by the platform, and at risk of been freeridden by other market participants, could be entitled to safeguards under competition law as long as they shown to have a competition-promoting effect. In general, hoteliers appreciate the marketing and advertising services that OTAs provide. ${ }^{87}$ The assumption here is that bundling advertising is in principle beneficial to small and medium-sized hotels. While a hotel can recoup pay-per-click advertisement costs if a consumer books a room in that specific hotel after having

\footnotetext{
${ }^{86}$ Düsseldorf Higher Regional Court, supra note 6.

87 See also the results of a survey conducted by the German competition authority as part of the Booking's investigation, see Bundeskartellamt, Booking, para $43 \mathrm{ff}$.
} 
clicked on a sponsored link ${ }^{88}$, the click is far from ensuring that the user will be making a booking in that specific hotel. Instead, for an OTA, it suffices if the consumer books any of the many hotels connected to the platform. An OTA can therefore in general achieve a much higher conversion ratio from bidding on search terms such as "hotels in Trento", than any individual hotel. ${ }^{89}$ Furthermore, small and medium-sized hotels are unlikely to possess the skills necessary in order for a successful bidding on keywords on search engines. It is not at all clear, however, that OTAs'online advertising services are so beneficial to individual hotels, and ultimately to end consumers, as it is argued. In particular, because of 'name grabbing', namely the purchase by OTAs from search engines of specific hotel names combined with the corresponding location information, the organic link to the hotel website (actually looked for by the customer) is not among the first results to appear on the search results page. Arguably, this makes it less likely for the end consumer to click on the direct link to the hotel's website. ${ }^{90}$ In a sort of vicious circle, higher OTA's advertising investments translate into hotel's stronger dependency, spiralling up commission fees, and inflated hotel room prices to the detriment of final customers.

A last and more general point is that, while withholding investments from which consumers would benefit can point to some form of suboptimality, even amidst the turmoil of the digital economy this could be a strong indicator of another type of flaw. The predicted fall in turnover, and the following draining of platform's investments into quality service, are premised on the assumption that, after the demise of the rate parity clause, the remuneration model would not change. Instead, as the Düsseldorf Higher Regional Court noted with regard to HRS, the platform had already

\footnotetext{
88 See also A. Ezrachi (2015), The Competitive Effects of Parity Clauses on Online Commerce, OECD Hearing on Across Platform Parity Agreements, p. 9 ("search terms such as 'Hotel Paris'...may go up to EUR 25 per click, regardless of whether that click led to a subsequent sale") available at http://www.oecd.org/officialdocuments/publicdisplaydocumentpdf/?cote=DAF/COMP(2015)11\& doclanguage $=$ en.

89 See the Swedish contribution to the OECD Hearing on across platform parity agreements (2015), p. 2. It is hardly a mystery that the major OTAs alone contribute to an appreciable extent to Google's overall advertising income, see Wall Street Journal, Google Checks In to the Hotel Business, April 8, 2014 ("Online travel agencies are among Google's biggest advertisers. Priceline Group will spend more than \$1.5 billion in 2014 on Google advertising and Expedia could spend another \$1 billion, mainly to attract hotel bookings").

90 Bundeskartellamt, Booking, § 279.
} 
successfully introduced a two-part system and there was no apparent decline in turnover. ${ }^{91}$ This shows that, despite the imperative to promote critical mass, the platform in many instances could react to the fact that users on one side profit from services for which they do not pay simply by mending the underlying business model. ${ }^{92}$ Quite clearly, the risk to avoid here is to bestow legitimacy on platforms and business models that happen to be profitable and viable thanks to some form of competition restriction.

\subsection{Fair share}

The second condition in Article 101(3) TFEU requires that, in order for a restrictive agreement to benefit from the exemption provided for in that provision, a 'fair share' of the efficiency gains resulting from anticompetitive agreements must be passed on to consumers. According to the Commission's 101(3) Guidelines, the concept of 'fair share' implies that the pass-on of benefits must at least compensate fully and effectively consumers for any actual or likely negative impact caused to them by the restriction of competition.

In its basic form, the 'pass-on' requirement reflects the need for efficiencies gains to redeem anti-competitive effects, and avoid unmitigated distribution of wealth from consumers to producers. In this respect, it is generally recognised that the second leg of Article 101(3) TFEU expresses a clear concern with distributional effects. ${ }^{93}$

At the same time, the consumer considered here is not only the final consumer, i.e. a natural person who is acting for purposes which are outside her trade or profession. ${ }^{94}$ In fact, the concept of consumers encompasses all direct or indirect users of the

\footnotetext{
${ }^{91}$ Düsseldorf Higher Regional Court, supra note 6.

92 Cfr. B. Warrington, Chasing the Uber model is killing a lot of on-demand companies, 8 May 2016, available at http://venturebeat.com/2016/05/08/chasing-the-uber-model-is-killing-a-lot-of-on-demandcompanies. See also infra Subsection 3.3.

${ }^{93}$ F. Ducci, Out-Of-Market Efficiencies, Two-Sided Platforms and Consumer Welfare: A Legal and Economic Analysis, Master Thesis, University of Toronto (2015), available at https://tspace.library.utoronto.ca/bitstream/1807/70296/3/Ducci_Francesco_201511_LLM_thesis.p df; I. Lianos, Some Reflections on the Question of the Goals of EU Competition Law, CLES Working Paper Series 3/2013 (2013); L. Parret, The Multiple Personalities of EU Competition Law: Time for a Comprehensive Debate on its Objectives, in D. Zimmer (ed.), The Goals of Competition Law, Cheltenham: Edward Elgar (2012).

94 101(3) Guidelines § 84.
} 
products or services covered by the agreement, such as final consumers, but also buyers of products for further processing and retailers.

In a first step, the 'pass-on' condition requires identification of the specific group of consumers in the relevant market affected by anti-competitive effects. As seen above, the rate parity clauses investigated in multiple competition regimes are to be found in the contracts between the OTAs and their respective partner hotels. The hoteliers demand intermediary services ("search, compare and book" bundle) from online platforms. In this market, where the OTAs are the suppliers and the hoteliers the customers, the latter pay for these advertising, comparison and brokerage services via a CPA fee that is levied every time a transaction (successful booking) takes place between the two user groups. The price structure is such that hoteliers bear all the costs for the services provided by the platforms to users on both sides of the business. In this context, the likely effect of the rate parity obligation is to increase prices of hotel rooms for final consumers. ${ }^{95}$ In this context, it is presumed that the benefit from a lower commission fees for the hotels would instead be passed-on to hotel customers as final consumers. Consumers affected by the vertical restraint in the relevant market are therefore hoteliers as direct users of the advertising, comparison and brokerage services offered by OTAs, alongside hotel customers as final consumers.

In a second step, the 'pass-on' condition requires balancing the competitive harm, namely the increased commission fees and hotel rooms, with the quality improvements. The 101(3) Guidelines specify that the claimed qualitative efficiencies (better services) should create "real value" for consumers in that market so as to compensate for the adverse effects of the restriction of competition. The second leg of the free-riding defence under Article 101(3) TFEU is satisfied if the benefits for platform users in terms of better service quality outweigh the negative effects on competition. This is likely to boil down to a value or "rough"6" judgment, as the precise

\footnotetext{
95 See supra Section 2.2.

96 H. Hovenkamp, Antitrust Law -1912i, at 371 (3d ed. 2011) ("[t]he set of rough judgments we make in antitrust litigation does not even come close to this 'balancing' metaphor").
} 
measurement of quality remains a very difficult enterprise. ${ }^{97}$ While the optimal level of quality for customers and, accordingly, their willingness to pay for the quality services cannot be determined reliably, the Bundeskartellamt deems it unlikely that customers would be willing to pay every price, or those prices allowing OTAs to recover all the investments they considered necessary to succeed in the market. ${ }^{98}$

A preliminary question in this context, however, is what are the quality services provided by the platform that could potentially outweigh anticompetitive effects. As seen above, an OTA commits substantial investments to the services directed to both hotels and to customers, directly and indirectly. Consumers benefit from the investments made by the OTAs, in the sense that they appreciate the services provided by the online booking platforms. Obviously, customers benefit directly from investments in the functionality of the platform and client, such as having a better performing search engine. Thus, for instance, reduced search costs are at the core of the general value that the OTA provides to final consumers. This type of advantages provided by platforms, however, are not decisive for the question whether consumers reasonably participate in the efficiencies generated by the vertical restraint under Article 101 (3) TFEU. In fact, not all investments withheld because of alleged freeriding can be considered part of the quality services that could outweigh anticompetitive effects. Consumer benefits in terms of Art. 101(3) TFEU are those deriving directly from the narrow MFN clause and not from the general value of the platform. More precisely, these should be investments that are first enabled by the narrow MFN clause. Because of the market failure, investments are withheld from which consumers could otherwise benefit in terms of better services. As seen above, however, it can be doubted whether rate parity clauses by their very nature are suitable to reinforce the already existing quality competition between OTAs and substantially increase the quality of the services provided by the platform for the real benefit of final consumers.

\footnotetext{
${ }^{97}$ EU Contribution to the OECD Roundtable on the Role and Measurement of Quality in Competition Analysis (2013), p. 81 available at http://www.oecd.org/competition/Quality-in-competition-analysis2013.pdf.

98 OECD/Germany (2015), supra note 63, § 22.
} 
Relatedly, final consumers in particular would generally benefit from services providing them with valuable information. It is very difficult, however, to find out exactly how consumers gather information about a specific accommodation offer. In specific contexts, those informational services could be more valuable, especially when alternative information service sources are scarce and/or complex.

At any rate, it is highly questionable whether and to what extent consumers could benefit from the high advertising expenditures of OTAs. This is true also for hoteliers, since, as seen above, in some instances high advertising expenditures by platforms can increase hoteliers' dependency and inflate commission fees.

Finally, the more serious the restriction of competition found under Article 101(1), the greater must be the efficiencies and the pass-on to consumers. ${ }^{99}$ As seen above, retail MFN clauses in practice may the same effects as a price fixing agreement. ${ }^{100}$ Therefore, it could generally be difficult to exempt them on the ground that they foster competition on some non-price dimensions, and in particular advertising, whose positive effects for consumers are already very doubtful. ${ }^{101}$

\subsection{The broader question of out-of-market efficiencies}

As seen above, the definition of 'consumer' under the second leg of Article 101(3) TFEU includes both intermediate customers (users) and final consumers. Interestingly, an OTA is an example of a two-sided platform where one group of users represents final consumers and the other intermediate customers, namely hoteliers who acquire a bundle of services from the platform and pay CPA fees.

The question inevitably arises whether, in order for the exemption provided for in Article 101(3) TFEU to be applicable in such a context, it is necessary that the fair share

\footnotetext{
${ }^{99}$ VR Guidelines, § 104: ("In cases where the likely effect of the agreement is to increase prices for consumers within the relevant market it must be carefully assessed whether the claimed (qualitative) efficiencies create real value for consumers in that market so as to compensate for the adverse effects of the restriction of competition.")

100 Supra Section 2.

101 OECD/Germany (2015), supra note 63, § 25. See also P. Buccirossi, Parity clauses: Economic incentives, theories of harm and efficiency justifications, Competition Law \& Policy Debate, 1(3) (2015), Symposium Parity Clauses, p. 43 (,After all, the same justification could also be provided for a cartel: the cartelists could argue that their price fixing agreement is aimed at fostering competition in non-price dimensions that require investments on which rivals can free-ride.").
} 
of the profit resulting from the advantages arising from the agreement is reserved for the consumers, both intermediate and final, of the services provided on the market on which the restrictive effects for competition are produced or whether it can be considered that the restrictive effects harming those consumers may be compensated by the advantages in favour of consumers of the services provided on a related market.

Competition enforcers have long recognised the possible multi-sidedness, or "out-ofmarketness", of efficiencies. ${ }^{102}$ According to settled case-law going back to a predigital era period, it is possible to take into consideration the advantages resulting from the agreement that occur on a different market from that on which the agreement produces the restrictive effects. ${ }^{103}$ According to the 101(3) Guidelines, such advantages can be taken into consideration where the category of consumers affected by the agreement and benefiting from the efficiency on the two separate markets are substantially the same. ${ }^{104}$ Arguably, there was uneasiness to accept that consumers affected by the negative effects of a restraint should pay for the benefits of other consumers in related markets. This underlies the rationale of allowing aggregation across markets exclusively when consumers are substantially the same.

More recently, the CJEU has made clear that, in the case of a two-sided platform, in order to assess whether an arrangement can fulfil the first condition laid down in Article 101(3) TFEU, it is necessary to take into account, where appropriate, all the objective advantages flowing from that measure not only on the market in respect of which the restriction has been established, but also on the market which includes the other group of users on the separate but connected market. ${ }^{105}$ It is indeed the very essence of online platforms to take into consideration, and mediate between, the interests of different user groups linked to each other through indirect network

\footnotetext{
102 The Commission has acknowledged out-of-market efficiencies under Article 101(3) TFEU for the first time in the Star Alliance commitment decision, see Commission Decision of 23 May 2013 in Case COMP/AT.39595 Continental/United/Lufthansa/Air Canada and A. Italiener, Competitor agreements under EU competition law, 40th Annual Conference on International Antitrust Law and Policy, Fordham Competition Law Institute, New York (2013), p. 11, available at http://ec.europa.eu/competition/speeches/text/sp2013_07_en.pdf.

103 Case T-86/95 Compagnie générale maritime and Others v Commission [2002] ECR II-1011, § 343; and Case T-168/01 GlaxoSmithKline Services v Commission [2006] ECR II-2969, § 248.

104 101(3) Guidelines, § 43.

105 MasterCard and Others $v$ Commission, supra note 70, § 237.
} 
effects $^{106}$ and the balancing exercise that multi-sided platforms typically carry out can generate conspicuous efficiencies. ${ }^{107}$ Therefore, it would seem rather inevitable, in view of the competition assessment of vertical restraints under Article 101(3) TFEU, to consider also the effects of agreements from which users on different sides of the platform would benefit directly. By broadening the scope of the efficiency assessment to be conducted under Article 101(3) TFEU when online platforms are involved ${ }^{108}$, the CJEU has contributed to the alignment of Article 101 TFEU with the ever more influential economics of two-sided markets.

More specifically, the recent MasterCard judgment ${ }^{109}$ states that, when examining the first condition laid down in Article 101(3) TFEU, it is necessary to take into account all the objective advantages flowing from the restraint, not only on the relevant market, but also on separate but connected market(s). Should it be found that there were "appreciable objective advantages" flowing from the restraint for the user group on the relevant market, even if those advantages did not in themselves prove sufficient to compensate for the restrictive effects identified pursuant to Article 101(1) TFEU, all the advantages for both user groups of an online platform, could, if necessary, still justify the agreement if, taken together, those advantages were of such a character as to compensate for the restrictive effects. ${ }^{110}$ Conversely, if there are no appreciable objective advantages for users on the relevant market, any advantages for the users on the connected market cannot in themselves sufficiently compensate for the restrictive effects, unless users in the two markets are substantially the same.

In their respective analyses, competition authorities online involved in the hotel booking cases have generally considered that there are strong indirect network effects between hoteliers and end customers. The larger the choice of hotels for a given destination, the more attractive an OTA is for prospective travellers; the larger the

\footnotetext{
106 Bundeskartellamt (2016), supra note 19, p. 14.

107 D. Evans and R. Schmalensee, The Antitrust Analysis of Multi-Sided Platform Businesses, NBER Working Paper 18783 (2013).

${ }^{108}$ Cfr. A. Scordamaglia-Tousis and C.-M. Carrega, The Application of Article 101(3) in the Context of MultiSided Markets Following MasterCard, Competition Policy International (2014), available at https://www.competitionpolicyinternational.com/assets/Uploads/EUDec14-2.pdf.

${ }_{109}$ MasterCard and Others v Commission, supra note 70.

110 Ibidem, § 241.
} 
number of prospective travellers using an OTA, the more attractive the online booking platform is for hoteliers. However, there was no attempt to quantify any related type of efficiency.

At any rate, it can very unlikely that the "appreciability" threshold could have been reached in the online hotel booking cases under analysis. In other balancing scenarios though two-sided-specific efficiency claims could become more relevant to competition assessment under Article 101(3) TFEU.111

\subsection{Alternatives to the Retail MFN Clause}

A further condition to be fulfilled for a successful free-riding defence is that the vertical restraint has to be indispensable within the meaning of Article 101(3) TFEU. In other words, the efficiency gains produced by the vertical restraint could not have been achieved through less restrictive means. For the cases under analysis, this means that the prerequisite condition for indispensability is that the rate parity obligation is reasonably necessary in order to achieve the efficiency gains. Conversely, justifications offered by OTAs based upon the efficiency of rate parity in inducing investments that promote competition may be rebutted where competitively less restrictive alternatives are found to be reasonably available.

Therefore, in a first step, it is necessary to assess whether there are realistic alternatives to rate parity which are less competition-restricting (a). In this regard, whether these models have already been actually put into practice in the relevant market should not be conclusive, as alternative business models might not have flourished on the relevant market also because of the effects of the competition restraint at work. Second, despite the existence of realistic, less restrictive alternatives, indispensability is proved if those alternatives would result in significant losses of efficiency (b)

\footnotetext{
111 For instance, it could be argued that users on one side of the market (hoteliers) may accept higher commission fees or other types of restrictive effect, because such a restriction is accompanied by better conditions to another user group that make the latter more likely to use the platform, so that the negative effects are somehow offset by increased use.
} 
a) Realistic alternatives

There are of course many alternative ways in order to solve a free-riding problem, also in the complex reality of two-sided businesses. The German competition authority considered an array of alternative business models, and came to the conclusion that they were realistic, partly because they were practiced in similarly structured markets. For instance, OTAs could provide services to hotels irrespective of the sales they generate, and hoteliers could pay for this service directly, for instance by way of "minimum guaranteed CPA rates". In this way, the amount of the compensation granted to the OTA could be structured as a function of the scope of the services actually rendered. To the extent that at least some hotels benefit from the „billboard effect" discussed above, they could be willing to pay such a fixed fee. A further alternative would be a business model that combines a fixed (lump-sum) fee for listing with variable compensation per booking, in addition to online advertising, as it is already common for price comparison websites in other sectors. ${ }^{112}$ Moreover, other business models in the hospitality industry already let the accommodation guest pay a fee for the platform services (es., Airbnb). Finally, more technological solutions to the free-riding problem could envisage the adoption of online tracking technologies similar to those already broadly employed by platforms in order to harness user data. In this way, a hotel that has received a booking via its own website following the guest's a visit to the platform could share the costs for the "search and compare" services previously used by the guest.

\footnotetext{
${ }_{112}$ Cfr. UK Financial Conduct Authority, Credit Card Market Study, Interim Report: Annex 7 - A Review of Price Comparison Websites (PCWs) (2015), available at http://www.fca.org.uk/static/documents/market-studies/ms14-6-2-ccms-annex-7.pdf, $\quad \S \quad 1.20$ ("PCWs may also promote specific credit card providers or their products in paid-for search and banner advertising and can be included in direct marketing by the PCW...A Arrangements are in place to ensure that PCWs receive commission for their services even if a consumer does not click through the link they provide (by the use of tracking cookies) ...There is a range of commission relationships, including payment on the number of click-throughs, a payment per application and payment per acquisition").
} 
b) Realistic and equally efficient alternatives

Once those alternatives are identified, the party has to demonstrate that those alternative models would be significantly less efficient than the previously used commission model. Clearly, the requirement is not met simply by demonstrating that most OTAs in the market are using it, in particular because this does not exclude that other, more efficient business models could have emerged in a market setting not vitiated by competition restraints. More efficient business model could emerge only after elimination of the vertical restraint.

Thus, with narrow retail MFN in place, the commission model currently employed by Booking, Expedia, HRS and other hotel online booking platforms is is surely the most profitable. Once rate parity eliminated, however, it cannot be excluded that OTAs would develop other remuneration models, or other solutions in general, in order to prevent free-riding in an equal or even more efficient way, in particular exploiting the the almost boundless potentials of new digital technologies.

\section{Conclusion: The Free-Riding Defence in the Digital Economy}

Two-sided platform businesses are at the core of the digital economy. As to OTAs, this new breed of intermediary has already disrupted long-established business practices in the hospitality industry. Given the many proved benefits of online platforms in general, extra caution is required when regulating them, and this applies also to competition policy.

Competition in digital markets, of course, cannot be adequately protected without first gaining in-depth insights on its concrete operation, and then providing suitable enforcement tools to fight its restraints. One of the main challenges faced by competition enforcers in this respect is that, given the current pace of technological innovation, market characteristics tend to evolve rather quickly. By the time the enforcer's arrow hits the target, the risk is that it might be too late to effectively wipe out the already ossified anticompetitive effects produced on the relevant market. 
From this perspective, the online hotel booking cases provided an important and timely opportunity to fine-tune the appropriate regulatory response to vertical restraints instigated by online platforms, and the learning curve faced by all the parties involved has been impressively steep.

As a matter of fact, the competition assessment of rate parity clauses poses a long series of difficulties, and the present contribution has highlighted at least some of them. Not only retail MFN is a new type of vertical restraint, but, more importantly, the actual relationship between the hotelier and the OTA has not much in common with the traditional manufacturer/retailer setting on which the competition policy on vertical restraints is firmly grounded.

Despite sailing in predominantly uncharted waters, NCAs in the EU were able to convincingly demonstrate that retail MFN clauses under certain circumstances can restrict competition among OTAs. This restriction causes an inflation of commission fees paid by hotels and, very likely, higher room prices for travellers. The NCAs, however, disagreed on the level of possible efficiency gains ensuing from narrow MFN clauses. In particular, the German authority, unlike the other NCAs, was unconvinced that this type of rate parity could effectively solve an alleged free-riding problem under the conditions set by Article 101(3) TFEU.

This contribution comes to the conclusion that the free-riding defence put forth by the OTAs in the hotel online booking cases was indeed rather weak. Under different circumstances, however, this justification could still successfully apply to vertical restraints, even between online platforms and their users. Moreover, novel efficiency defences are likely to apply to two-sided platform business. While not a swan song for the free-riding defence, the hotel online booking saga makes once more clear that efficiency allegations of this type need to be carefully and thoroughly assessed, especially in digital markets. 